Original Research Paper

\title{
Penguatan Jiwa Kewirausahaan Perempuan Pesisir Melalui Pengolahan Pangan
}

\section{Lokal}

\author{
Ika Wijayanti' ${ }^{*}$, Lalu Wirespta Karyadi $^{1}$, Maya Atri Komalasari ${ }^{1}$ \\ ${ }^{1}$ Universitas Mataram, Mataram, Indonesia
}

https://doi.org/10.29303/jpmpi.v3i2.966

Sitasi: Wijayanti, I., Karyadi, L. W \& Komalasari, M. A. (2021). Penguatan Jiwa Kewirausahaan Perempuan Pesisir Melalui Pengolahan Pangan Lokal. Jurnal Pengabdian Magister Pendidikan IPA, 4(3)

\section{Article history}

Received: 30 Agustus 2021

Revised: 17 September 2021

Accepted: 18 September 2021

*Corresponding Author: Uswatun Khasanah,

Universitas Mataram,

Mataram, Indonesia.

Email:

ikawijayanti@unram.ac.id

\begin{abstract}
Kondisi pandemi covid 19 memberikan dampak yang signifikan tehadap perempuan pesisir baik dari segi ekonomi maupun kesehatan. Perempuan pesisir khususnya di desa Tanjung Karang Kota Mataram sebagian besar berprofesi sebagai pedagang ikan mengalami penurunan omset penjualan ikan dan hasil olahannya. Gempa bumi, penurunan kunjugan wisatawan dan pandemi covid 19 merupakan rangkaian momentum yang memberikan dampak bertubitubi. Perempuan pesisir desa Tanjung Karang berupaya mengembangan berbagai strategi untuk mempertahankan ekonomi keluarganya di tengah kondisi pandemi covid 19, salah satunya adalah meminjam uang pada penyedia jasa pinjaman seperti koperasi, bank, hingga pinjaman yang berbunga tinggi. Kegiatan pengabdian masyarakat berjudul Penguatan Jiwa Kewirausahaan Perempuan Pesisir Melalui Pengolahan Pangan Lokal di desa Tanjung Karang Kota Mataram urgen dilakukan mengingat dampak yang dirasakan oleh perempuan pesisir akibat pandemi covid 19. Kegiatan pengabdian masyarakat diikuti oleh perempuan pesisir desa Tanjung Karang yang memiliki beragam profesi khususnya penjual dan pengolah ikan. Rangkaian kegiatan pengabdian masyarakat yaitu dengan memberikan pelatihan pembuatan sirup jahe dan rempah-rempah, FGD (Focus Grup Discussion) serta materi penguatan finansial ekonomi rumah tangga. Pelatihan pembuatan sirup jahe dan rempah dipilih karena bahan pangan lokal tersebut mudah didapat, memberikan peluang usaha di tengah pandemi, serta dapat menjadi alternatif penyokong imunitas tubuh. Output dari pengabdian ini adalah meningkatkan pemahamanan perempuan pesisir akan pentingnya mencari peluang-peluang usaha untuk meningkatkan ekonomi keluarga sehingga tidak bergantung pada pinjaman finansial..
\end{abstract}

Keywords: tpa nurul huda, improving memorization skills, al-qur'an memorization animation

perikanan dan pariwisata. Kawasan Bali dan Nusa Tenggara merupakan daerah penangkapan ikan laut yang potensial termasuk Pulau Lombok.

Walaupun potensi hasil laut Pulau Lombok cukup menjanjikan, namun pada kenyataannya masyarakat pesisir masih banyak dalam kategori masyakarat miskin atau dengan tingkat kesejahteraan yang rendah. Sebagian besar penduduk yang menempati wilayah pesisir pada 
umumnya memiliki mata pencaharian sebagai nelayan dengan pola penangkapan ikan yang masih konvensional. Nelayan bekerja bergantung pada iklim sehingga pendapatan yang diperoleh pun tidak menentu. Data Badan Pusat Statistik tahun 2016 mencatat bahwa komunitas pesisir berkontribusi terhadap kemiskinan sekitar 25,14\% atau 7,87 juta jumlah orang miskin di Indonesia (bps.go.id).

Dilansir dari harian today line, kondisi perekonomian masyarakat nelayan di Pulau Lombok dari awal tahun 2021 cukup memprihatinkan. Kondisi cuaca yang tidak menentu mengakibatkan nelayan sulit untuk melaut. Perkiraan cuaca buruk dan gelombang besar ditengarai akan terjadi hingga Maret. Pekerjaan alternatif seperti menjual jasa dan buruh bangunan juga makin sulit akibat kondisi pandemi covid

(https://today.line.me/id/v2/article/j9eLBL).

Kebutuhan yang terus meningkat dan tidak dibarengi dengan pendapatan yang seimbang membuat nelayan terpaksa menjual barang-barang rumah tangga hingga meminjam kepada koperasi, bank, serta pemberi bungan dengan pinjaman tingggi. Pinjaman kepada pihak-pihak tersebut ternyata tidak hanya dilakukan oleh nelayan namun juga istri. Hal ini dikarenakan aktivitas perikanan tidak haya berpusat pada nelayan laki-laki saja namun juga perempuan yang menggantungkan profesinya pada sektor perikanan seperti penjual ikan dan pengolahan hasil laut.

Himpitan ekonomi memaksa para perempuan istri nelayan meminjam kepada rentenir dengan motif yang berbeda. Berdasarkan observasi, motif pinjaman beragam dari pinjaman modal, untuk keperluan barang rumah tangga, hingga konsumsi sehari-hari. Meminjam kepada rentenir dinilai lebih mudah dan cepat tanpa syarat dan jaminan yang menyulitkan para perempuan pesisir. Alternatif ini dilakukan karena nelayan dan perempuan pesisir sulit mendapatkan akses pinjaman ke bank walaupun para perempuan juga ada yang memiliki usaha kecil-keclan. Meskipun resikonya adalah bunga pinjaman yang tergolong besar dan pola tagihan pembayan yang cukup mengusik, para perempuan pesisir khususnya di Desa Tanjung Karang terpaksa meminjam kepada pemberipinjaman finansial walau dengan bunga besar.
Besaran pinjaman tidaklah sama tergantung kebutuhan si peminjam, namun rata-rata bunganya 10-20\%. Tidak hanya itu, perempuan pesisir yang meminjam kepada rentenir juga dibebani dengan pembayaran setiap hari dengan nominal yang telah disepakati. Pola pembayaran kepada rentenir ini menimbulkan istilah yang cukup menarik terhadap peminjam misalnya "bank rontok" hal ini karena pinjaman membuat jiwa dan raga terkuras habis. Ada juga dikenal "bank tongol" karena sang penagih datang setiap hari. Keputusan perempuan meminjam kepada rentenir tidaklah selamanya menyelesaikan masalah, justru semakin menambah beban ekonomi keluarga dengan sistem bunga yang besar. Ketidakberdayaan perempuan pesisir inilah yang menjadi urgen untuk dilakukan pengabdian. Penguatan jiwa kewirausahaan penting dilakukan agar pelan-pelan perempuan pesisir dapat mandiri dan keluar dari jerat pinjaman finansial dalam masa pandemi covid 19.

Pandemi covid 19 yang melemahkan ekonomi perempuan pesisir menjadi tantangan untuk mencari alternatif pendapatan. Pengabdian masyakat dengan memberdayakan masyarakat melalui penguatan jiwa kewirausahaan memberikan skill pelatihan pembuatan sirup jahe dan rempah sebagai bahan pangan lokal untuk menaikkan nilai ekonomi. Bahan pangan lokal tersebut dipilih karena mudah didapat dan diakses oleh peserta pengabdian. Selain dapat meningkatkan nilai ekonomis dari bahan pangan lokal, sirup jahe dapat dikonsumsi menjadi alternatif penguat imunitas tubuh pada masa pandemi covid 19 seperti sekarang ini. Melalui upaya pemberdayaan, masyarakat didorong agar memiliki kemampuan untuk memanfaatkan sumberdaya yang dimilikinya secara optimal serta terlibat secara penuh dalam mekanisme produksi, ekonomi, sosial dan ekologinya (Mardikanto dan Soebianto, 2015).

Tujuan dari pengabdian masyarakat ini adalah untuk memberikan bekal ketrampilan mengolah bahan pangan lokal khususnya jahe dan rempah-rempah untuk menaikkan nilai guna sehingga menjadi inovasi dalam peluang usaha. Selain itu, melaksanakan sebuah pemberdayaan partisipasif yang bertujuan 1) untuk menggali kesulitan-kesulitan perempuan pesisir pada masa pandemi covid 19 2) strategi perempuan pesisir dalam menjalankan ekonomi pada masa pandemi. 


\section{Metode}

Kegiatan pengabdian kepada masyarakat yang berjudul Penguatan Jiwa Kewirausahaan Perempuan Pesisir Melalui Pengolahan Pangan Lokal dilaksanakan pada hari kamis tanggal 9 September 2021 di aula TPQ Desa Tanjung Karang, Kelurahan Tanjung Karang, Kota Mataram. Kegiatan dilaksanakan pada pukul 16.00 Wita sampai pukul 18.00 Wita. Waktu tersebut ditentukan dengan pertimbangan tidak mengganggu aktivitas perempuan pesisir sebagai peserta pengabdian.

Pelaksanaan kegiatan pengabdian kepada masyarakat dilakukan dengan metode Focus Group Discussion, pemberian pelatihan, dan sosialisasi atau pemaparan materi. Tujuan utama dari Focus Group Discussion adalah untuk menggali pengetahuan masyarakat mengenai dampak pandemi covid 19 pada ekonomi rumah tangga dan profesi peserta pengabdian masyarakat. Hal lain yang dieksplorasi adalah terkait bagaimana strategi hidup perempuan pesisir di tengah terpaan dampak covid 19. Kegiatan berikutnya adalah dengan pemberikan skilll atau ketrampilan pembuatan sirup jahe dan rempah-rempah, peluang usaha sirup jahe di masa pandemi covid 19, analisis keuntungan dan strategi pemasarannya. Peserta pengabdian masyaakat diberi kesempatan untuk mencoba bagaimana cara membuat dan mencicipi hasil pelatihan. Pada sesi ini, peserta pegabdian diberikan kesempatan taya jawab dan diskusi terbuka oleh pemateri.

Kegiatan berikutnya dilakukan dengan memberikan sosialisasi dan pemaparan materi yang dilakukan secara bergiliran oleh pemateri. Sesi ini memberikan pemahaman peserta pengabdian terkait bagaimana mengelola finansial rumah tangga, memprioritaskan kebutuhan dan saving pada masa pandemi covid 19. Melaui serangkaian kegiatan Focus Group Discussion, pemberian pelatihan pengolahan pangan lokal, dan sosialisasi pengabdian masyaakat dapat memberikan gambaran inovasi untuk meningkatkan ekonomi rumah tangga dengan memanfaatkan peluang yang ada.

\section{Hasil dan Pembahasan}

\section{a. Pelatihan Pengolahan Pangan Lokal Untuk Penguatan Jiwa Kewirausahaan}

Kurangnya jiwa inovasi dan kreasi, menurunnya omset penjualan, serta himpitan ekonomi pada masa pandemi covid 19 membuat perempuan pesisir terpaksa meminjam kepada pihak pemberi pinjaman. Oleh karena itu memberikan penguatan kapasitas perempuan pesisir dalam memanagemen keuangan dan memberikan penguatan jiwa kewiraushaan sangat diperlukan. Penguatan jiwa kewirausahaan merupakan langkah yang sangat perlu dilakukan sebagai suatu titik tolak utama dari penguatan perempuan pesisir.

Pelatihan pengolahan pangan lokal yaitu dengan membuat sirup jahe yang belum pernah dicoba dan dikonsumsi oleh peserta pengabdian serta mudah dipraktekkan. Selama ini peserta pengabdian hanya mengonsumsi jamu dari rimpang-rimpang termasuk jahe tanpa mengolah menjadi barang bernilai ekonomis. Bahan pangan lokal yang diolah antara lain jahe sebagai bahan utama, yang bervariasi dari jahe merah, jahe emprit dan jahe gajah. Adapun komposisi bahan sirup jahe adalah sebagai berikut.

- $\quad$ Jahe merah/jahe emprit/jahe gajah $=1 \mathrm{~kg}$

- $\quad$ Air (perbandingan air dan jahe $=2$ liter air untuk $1 \mathrm{~kg}$ jahe)

- $\quad$ Sereh 7 batang

- $\quad$ Kayu manis kurang lebih $10 \mathrm{~cm}$

- $\quad$ Segenggam kapulaga

- $\quad$ Cengkeh kurang lebih 25 butir

- $\quad$ Gula pasir 3/4 kg

- $\quad$ Gula aren/gula merah $1 / 4 \mathrm{~kg}$

Cara pembuatannya yaitu sebagai berikut.

Jahe dibersihkan bisa dengan mencuci bersih atau dikupas kulitnya, selanjutnya diparut atau diblender. Untuk mendapatkan kekentalan sirup jahe yang bagus, lebih baik menghaluskan jahe dengan cara di parut. Saring untuk mendapatkan air jahe Tuang air saringan jahe ke panci, tambahkan air, didihkan dengan api kecil, aduk agar tidak terjadi penggumpalan sari pati jahe di dasar panci. 
Setelah mendidih tambahkan rempahrempah seperti cengkih, kayu manis, sereh, dan kapulaga serta sedikit garam, biarkan mendidih hingga setengah jam.

Tuang gula pasir dan gula merah/aren aduk-aduk untuk menghindari karamelisasi, setengah jam kemudian matikan api, tunggu hingga dingin, siap dikonsumsi dan dikemas.

Pengetahuan lokal perempuan pesisir terhadap pengolahan bahan pangan sebenarnya telah dimiliki oleh para peserta pengabdian seperti pengetahuan manfaat jahedan rempah untuk menjaga kesehatan. Hal ini tentunya akan menjadi modal dalam pengembangan usaha alternatif selain penjualan dan pengolahan ikan. Kurangnya inovasi dan kreasi menjadi kendala dalam mengeksplor pegetahuan lokal tersebut. Pengabdian ini memberikan Kontribusi mendasar pada khalayak sasaran yaitu meningkatkan pemahamanan perempuan pesisir akan pentingnya menguatkan jiwa kewirausahaan untuk meningkatkan ekonomi keluarga sehingga tidak bergantung pada pola aktivitas penjualan ikandan pengolahan hasil laut yang sangat tergantung pada musim dan pinjaman modal ke bank, rentenir, koperasi dan sebagainya.

\section{b. Sosialisasi dan Pemaparan Materi terkait Pentingnya Kemandirian Finansial bagi Perempuan}

Kemandirian merupakan kemampuan dan keterampilan yang penting dalam menjalani kehidupan. Dari asal katanya, mandiri diartikan sebagai keadaan dapat berdiri sendiri; tidak bergantung pada orang lain: sejak kecil ia sudah biasa -- sehingga bebas dari ketergantungan pada orang lain, dan kemadirian dimaknai sebagai hal atau keadaan dapat berdiri sendiri tanpa bergantung pada orang lain (https://kbbi.web.id/mandiri). Dari pengertian tersebut, maka kemadirian merujuk pada suatu keadaan yang menunjukkan kemampuan pada diri sendiri atau tidak bergantung pada pihak lain.

Setiap orang pada dasarnya memerlukan kemampuan untuk mandiri baik laki-laki maupun perempuan, terlebih dalam hal kemadirian finansial atau keuangan.
Secara umum mandiri finansial adalah suatu kondisi keuangan dimana seseorang memiliki penghasilan sendiri, mampu mengelola uang sendiri, dan tidak lagi bergantung kepada orang lain, seperti orangtua, kerabat atau pasangan (Jatmiko, 2020). Kemandirian finansial menjadi semakin penting dimiliki tiap orang mengingat manfaatnya membuat seseorang mampu mengelola keuangannya dengan baik hingga memperkecil peluang terjerat hutang dan bahkan bukan tidak mungkin malah mampu berinvestasi.

Kemadirian ekonomi, atau finansial menjadi salah satu kemandirian yang sangat penting dimiliki khususnya bagi kaum perempuan (Basukiyanto, 2003; Dzulkarnain et.al, 2013). Kemandirian finansial atau dalam keuangan, berarti perempuan dapat memperoleh penghasilan sendiri ataupun mengelolanya dengan baik. Kondisi kemandirian tersebut berarti memberikan perempuan tersebut kekuatan dalam mengambil keputusan, terutama keputusan yang tentu saja krusial dan berpengaruh kepada kehidupan, tanpa bergantung pada sumber keuangan yang lain (https://www.permatabank.com/id/article/penti ngnya-perempuan-mandiri-secara-finansial).

Secara sederhana, kemandirian finansial menjadikan perempuan mampu menentukan pilihan-pilihan atau keputusan-keputusan penting dalam kehidupannya tanpa adanya ketergantungan dari pihak lain.

Kemandirian finansial bagi perempuan inipun berguna bagi seluruh perempuan, baik yang sudah menikah maupun yang masih lajang. Artinya kemandirian finansial bagi perempuan berguna tanpa kecuali. Bagi perempuan yang sudah menikah, mandiri secara finansial ini berarti menjadikan penghasilan sebagai 'pos cadangan' yang bisa jadi bantuan berarti saat keluarga mengalami musibah yang tidak diinginkan dan dapat meringankan beban finansial sang suami, sedangkan bagi perempuan yang belum menikah, mandiri secara finansial memberi kekuatan yang serupa untuk digunakan pada diri sendiri, dengan tidak bergantung sama sekali kepada orang lain, termasuk kepada orang 
(https://www.permatabank.com/id/article/penti ngnya-perempuan-mandiri-secara-finansial).

Adanya kemadirian finansial pada perempuan mendorong ketangguhan perempuan. Perempuan menjadi sosok yang bisa diandalkan minimal untuk diri mereka sendiri dan bahkan bagi keluarga jika perempuan tersebut telah menikah. Karena tidak dipungkiri bahwa ketidakmandirian secara finansial memiliki dampak yang kurang baik. Berdasarkan laporan tahun 2020 tentang kekerasan dalam rumah tangga, kekerasan dalam rumah tangga masih tinggi dan mayoritas perempuan sebagai korban dan hal tersebut terjadi akibat masalah krisis keuangan yang mengarah pada peningkatan perilaku kekerasan, mayoritas korbannya adalah perempuan

(https://investor.id/editorial/245139/perempua n-mandiri-secara-finansial). Dengan kata lain jika perempuan mampu mandiri secara finansial artinya mampu memperkecil adanya potensi kekerasan rumah tangga yang sangat mungkin timbul karenanya. Kondisi keuangan atau finansial yang stabil maka hal tersebut menjauhkan keluarga dari krisis keuangan yang bukan tidak mungkin berubah menjadi krisis yang mengancam bagi keutuhan keluarga.

Mandiri secara finansial bagi perempuan, terutama perempuan pesisir seperti di Lingkungan Sembalun, Kelurahan Tanjung Karang, Kecamatan Sekarbela, Kota Mataram bukanlah suatu yang sulit. Disebabkan hal tersebut dapat diwujudkan dengan upaya-upaya yang sederhana namun konsisten atau berkelanjutan. Walaupun begitu, tetap adanya prinsip-prinsip pokok yang harus dilakukan sebagai kuncinya. Berbagai prisip tersebut meliputi: 1). Penghasilan dari gaji atau pemasukan lainnya harus dikelola secara baik dengan mengutamakan penghasilan untuk dialokasikan pada kebutuhan-kebutuhan primer, 2). Memastikan setiap bulannya ada uang yang dapat disisihkan untuk ditabung atau investasi, 3). Pengeluaran harus diatur secara cermat setiap bulannya. Kebutuhan pokok harus menjadi prioritas belanja bulanan, termasuk menghindari belanja berlebihan untuk barang-barang yang bukan kebutuhan pokok, apalagi hanya untuk memenuhi gaya hidup. Hal ini mencakup penyesuaian gaya hidup dengan kemampuan finansial agar tidak boros dalam pengeluaran yang pada akhirnya akan menambah beban keuangan karena terlilit hutang (https://investor.id/editorial/245139/perempua n-mandiri-secara-finansial).

Materi sosialisasi mengenai Pentingnya Kemandirian Finansial Perempuan yang disampaikan antaralain: 1) pengertian tentang kemadirian secara umum, 2).pengertian kemandirian secara finansial, 3). Perlunya Kemandirian Finansial bagi perempuan dan 4) Upaya-upaya yang dilakukan agar Perempuan Mandiri secara Finansial. Setelah dipaparkan berbagai materi tersebut dilanjutkan dengan FGD dengan para peserta perempuan yang hadir. Pada kegiatan tersebut terjalin terdapat pula proses tanya jawab antara tim pengabdian masyarakat dengan para peserta.

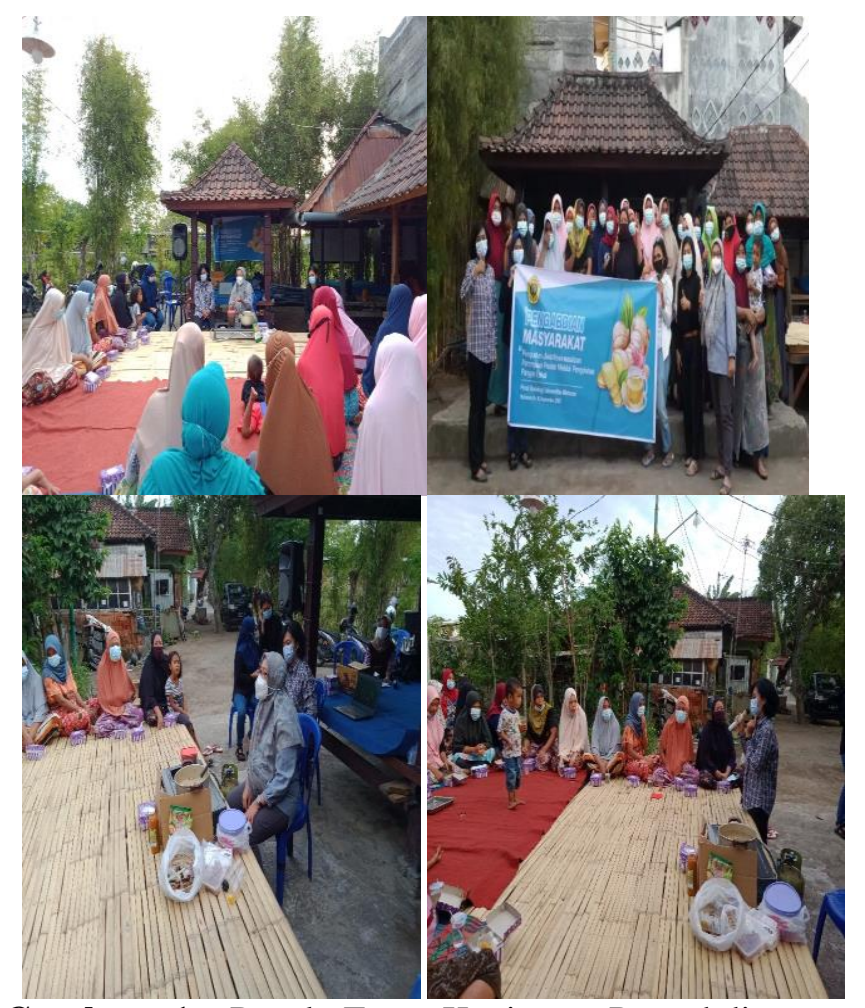

Gambar 1. Panel Foto Kegiatan Pengabdian Masyarakat Penguatan Jiwa Kewirausahaan Perempuan Pesisir Melalui Pengolahan Pangan Lokal 


\section{Kesimpulan}

Kegiatan pengabdian masyarakat terhadap perempuan pesisir di Kelurahan Tanjung Karang, Kota Mataram menghasilkan hasil-hasil yang penting. Pertama, peserta pengabdian masyarakat mampu mengetahui dan memahami cara pengolahan bahan pangan agar lebih ekonomis melalui pembuatan sirup jahe. Dengan hal tersebut, membuka peluang usaha atau kewirausahaan yang dapat mereka lakukan karena tidak memerlukan modal yang terlalu banyak dan bahan-bahan yang mudah didapat. Kedua, perempuan pesisir yang notabene merupakan ibuibu rumah tangga dan penjual ikan mampu mengetahui pentingnya kemandirian finansial bagi kehidupannya, serta bertekad untuk melakukan upaya-upaya mewujudkannya secara konsisten. Saran untuk kegiatan pengabdian masyarakat yang dapat dilakukan selanjutnya dapat memiliki waktu yang cukup panjang.

\section{Ucapan Terima Kasih}

Atas terselenggaranya kegiatan pengabdian kepada masyarakat ini, penulis mengucapkan terima kasih kepada Lembaga Penelitian dan Pengabdian Masyarakat (LPPM) Universitas Mataram yang telah memberi dukungan finansial terhadap pengabdian ini. Penulis juga mengucapkan terimakasih pada Pemerintah Kelurahan Tanjung Karang, Kecamatan Sekarbela, Kota Mataram yang telah mengizinkan dan menjadi tempat berlangsungnya kegiatan pengabdian masyarakat ini.

\section{Daftar Pustaka}

Basukiyanto, 2003. Peranan Kemandirian Wanita Dalam Mendukung Usaha Keluarga. Cermin Majalah Ilmiah Universitas Pancasakti Tegal Edisi 034 / Agustus 2003

Damsar dan Indrayani. 2013. Sosiologi Ekonomi. Jakarta: Prenada Media

Dzulkarnain, Iskandar, Faidol, Aminah Dewi Rahmawati, H. Mohammad Djasuli. 2013. Kemandirian Perempuan Dalam Mengelola Remitan Melalui Lembaga Keuangan Mikro Syari'ah Program Grameen Bank. Karsa, Vol. 21, No. 1 Juni 2013
Fakih, Mansour. 2012. Analisis Gender dan Transformasi Sosial. Yogyakarta: Pustaka Pelajar.

Goode, William J. 1995. Sosiologi Keluarga. Jakarta: Bumi Aksara

http://www.policy.hu/suharto/modul_a/makindo_07 $\underline{\mathrm{htm}}$

https://investor.id/editorial/245139/perempuanmandiri-secara-finansial

https://www.permatabank.com/id/article/pentingny a-perempuan-mandiri-secara-finansial

Hunga, Ina dan Dewi Candraningrum. 2017. Ekofenimisme IV (Tanah, Air, dan Rahim Rumah). Salatiga: Parahita Press

Ihromi. 2004. Bunga Rampai Sosiologi Keluarga. Jakarta: Obor Indonesia.

Jatmiko, Bambang P. 2020. 5 Ciri Milenial Mandiri Finansial, Kamu Masuk yang Mana? Diakses dari https://money.kompas.com/read/2020/08/10/ 153000626/5-ciri-milenial-mandiri-finansial$\underline{\text { kamu-masuk-yang-mana-?page }=\text { all }}$

Mardikanto, Totok dan Poerwoko Soebianto. 2015. Pemberdayaan Masyarakat Dalam Perspektif Kebijakan Publik. Bandung: Alfabeta.

Sajogyo, Pudjiwati. 1989. Sosiologi Pembangunan. Jakarta: IKIP Jakarta.

Soekanto, Soerjono. 2009. Sosiologi Keluarga. Jakarta: Rineka Cipta.

Suwarsono dan Alvin. 2013. Perubahan Sosial dan Pembangunan. Jakarta: LP3ES 